\title{
In the Public Interest': The Responsibilities and Rights of Government Lawyers
}

Allan C. Hutchinson

Osgoode Hall Law School of York University, ahutchinson@osgoode.yorku.ca

Follow this and additional works at: http://digitalcommons.osgoode.yorku.ca/ohlj

Part of the Legal Ethics and Professional Responsibility Commons, and the Legal Profession Commons

Article

\section{Citation Information}

Hutchinson, Allan C.. "In the Public Interest': The Responsibilities and Rights of Government Lawyers." Osgoode Hall Law Journal 46.1 (2008) : 105-129.

http://digitalcommons.osgoode.yorku.ca/ohlj/vol46/iss1/3 


\title{
In the Public Interest': The Responsibilities and Rights of Government Lawyers
}

\begin{abstract}
While considerable thought and effort have been put into exploring and fixing the ethical rights and professional responsibilities of private Lawyers, little energy has been directed towards defining and defending the role and duties of government lawyers. As a result, the traditional understanding seems to be that government lawyers are to consider themselves as being under the same regimen and restrictions as their private counterparts. After criticizing this default approach, the article offers a fresh evaluation of what is different about the role of government lawyers and develops a more appropriate model for thinking about their professional responsibilities and ethical privileges. The central thrust of the article is the effort to appreciate legal ethics and professional responsibility as part of a larger democratic understanding of law and justice.
\end{abstract}

Keywords

Legal ethics; Government attorneys 


\title{
'In the Public Interest': The Responsibilities and Rights of Government Lawyers
}

\begin{abstract}
ALLAN C. HUTCHINSON *
While considerable thought and effort have been put into exploring and fixing the ethical rights and professional responsibilities of private lawyers, little energy has been directed towards defining and defending the role and duties of government lawyers. As a result, the traditional understanding seems to be that government lawyers are to consider themselves as being under the same regimen and restrictions as their private counterparts. After criticizing this default approach, the article offers a fresh evaluation of what is different about the role of government lawyers and develops a more appropriate model for thinking about their professional responsibilities and ethical privileges. The central thrust of the article is the effort to appreciate legal ethics and professional responsibility as part of a larger democratic understanding of law and justice.
\end{abstract}

Quelle que soit la somme de réflexion et d'effort consacrée à explorer et à fixer les droits éthiques et les responsabilités professionnelles des avocats privés, on a consacré peu de temps à définir et à défendre le rôle et les devoirs des avocats du gouvernement. Par conséquent, on s'accorde traditionnellement à dire que les avocats du gouvernement doivent considérer qu'ils relèvent du même régime et respectent les mêmes restrictions que leurs homologues privés. Après avoir critiqué cette " approche par défaut », l'article offre une évaluation neuve des différences sur le plan du rôle des avocats du gouvernement. Il développe un modèle plus appropriè de réflexion au sujet de leurs responsabilités professionnelles et de leurs privilèges éthiques. L'argument central de cet article fait ressortir l'effort d'apprécier les éthiques juridiques et la responsabilité professionnelle dans le cadre d'une perception démocratique large du droit et de la justice.

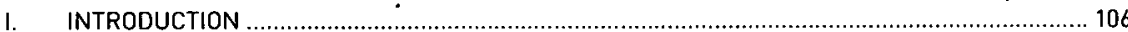

II. DEMOCRACY AND LEGAL ETHICS.

* Distinguished Research Professor, Osgoode Hall Law School, York University. I am grateful to Andrew Kaufman, Trevor Farrow, Adam Dodek, and Lorne Sossin for their critical comments and helpful suggestions. 


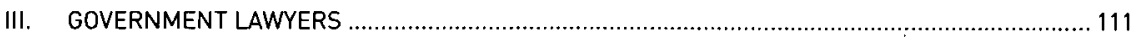

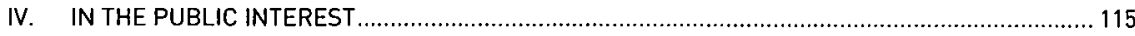

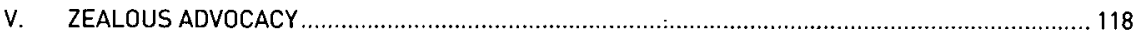

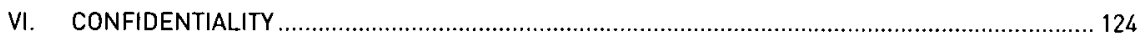

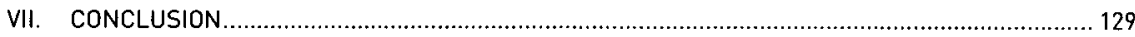

\section{INTRODUCTION}

GOVERNMENT LAWYERS ARE the orphans of legal ethics. While considerable thought and effort have been put into exploring and fixing the ethical rights and professional responsibilities of private lawyers, little energy has been directed towards defining and defending the role and duties of government lawyers. Not only do the various official codes of professional conduct remain almost silent in their applicability to government lawyers, there is also a paucity of academic literature and professional commentary about how these lawyers are supposed to approach their working obligations and institutional imperatives. As a result, the traditional understanding seems to be that government lawyers are to consider themselves subject to the same regimen and restrictions as their private counterparts. Yet this default approach is obviously wanting in many regards. In particular, it fails to appreciate the important differences between the functions of government lawyers and private lawyers and, therefore, fails to recognize that the ethical duties and professional obligations imposed on private lawyers do not transfer easily or usefully to the different context of government lawyers. Consequently, as the number and importance of government lawyers continue to grow, it is more than timely to offer a fresh evaluation of what is different about the role of government lawyers and to develop a more appropriate model for thinking about their professional responsibilities and ethical privileges. This short article is an attempt to begin that important theoretical task.

The central thrust of this article sees legal ethics and professional responsibility as part of a larger democratic understanding of law and justice. While a democratic focus has commanded the attention of most commentators when it comes to assessing the appropriate role of judges in fulfilling their common law and constitutional duties, there has been almost no corresponding 
democratic concern with the professional role of lawyers.' The relationship between democracy and legal ethics tends to be stated implicitly and viewed as secondary, even though many similar dilemmas and challenges arise in both the lawyering context and the adjudication realm. Accordingly, I make an initial foray into this neglected field and put a democratic sensibility at the heart of my approach to reframing the responsibilities of government. After exploring the democratic basis for the traditional private model of ethical lawyering, I look to how the concept of the "public interest" might be relied on to illuminate the context in which government lawyers work and the implications this has for their ethical obligations. Of course, democracy is one of the most contested terms in the legal and political lexicon, having almost as many meanings as there are democrats. While it is important to be sensitive to such divisions of opinion, this ought not to present an insuperable obstacle to grounding some general and broad observations about the role and responsibilities of government lawyers in a democratic society. Moreover, the application of such an approach to legal ethics recommends that some traditional understandings of government lawyers' ethical duties and professional constraints (e.g., zealous advocacy and confidentiality) may need to be reformulated and reworked.

\section{DEMOCRACY AND LEGAL ETHICS}

Although there is much debate and disagreement over democracy's precise meaning and requirements, its core commitment is to the understanding that people should rule over themselves. Treated as having procedural (e.g., participation, voting) and substantive (e.g., security, welfare) dimensions, albeit both heavily contested, strong democracy is committed to the idea and practice that governance is to be for the people and, as importantly, by the people. However, the realities of modern states and large-scale governance mean that democratic proponents must be prepared to compromise on some of democracy's more idealistic aspirations if they are to be implemented in an

1. Of course, the democratic focus on adjudication has not led to any agreement on what adjudication is and ought to be about. Nevertheless, there is almost universal agreement that the effort to understand adjudication in democratic terms is one of the compelling mandates of judicial scholarship. See e.g. Kent Roach, The Supreme Court on Trial: Judicial Activism or Democratic Dialogue (Toronto: Irwin Law, 2001). 
efficient and efficacious manner. Like most political theories, therefore, democracy focuses on the distribution and exercise of power. Democrats are concerned less with power in itself and more with the basis on which it is allocated, with how it is exercised, and with the use to which it is put. At bottom, democracy seems to involve a recognition that power should be devolved and shared, and when that is not practicable, that power be exercised by those democratically authorized to do so with responsibility and accountability. Consequently, modern democratic governance effects a practical compromise by establishing a system of governance that is at least for the people if it is not always by the people. It does this by ensuring a division of powers and responsibilities among institutions and actors so that the allocation and exercise of power is diffuse, disciplined, conditional, temporary, and accountable. The basic gamble is that although a gap between the rulers and the ruled and between the powerful and the powerless will persist, the smaller the gap and the better its means of scrutiny, the more democratic the society will be. ${ }^{2}$

However, if democracy is to make good on its emancipatory promise, it must be willing to confront and eradicate abuses of power from whatever source they arise. From a citizen's perspective, it surely makes little difference whether the concentration of power and its exercise is technically public or private in origin. In particular, sustained efforts must be made to ensure that power is not held by a small group of elites and exercised with litrle regard to the interests of others. In an important sense, the key contemporary challenge remains as much about whether the majority will ride roughshod over the minority as whether a privileged minority—be it the monied few, the judicial aristocracy, the political elite, the bureaucratic oligarchy, the corporate nabobs or, of course, the legal profession - will ride roughshod over the majority. Democracy is devoted to exerting a centrifugal rather than centripetal influence on power. Too often, democracy and its institutions have been hijacked by the elite, even if claiming to speak and act for the interests of all Canadians. This is more a form of benevolent despotism which, no matter how benevolent, remains despotic and cannot be democratic in operation or effect. Accordingly, democracy demands neither that the majority oppress the minority nor that the minority rule over the majority. Both are anathema to the democrat.

2. For my own general stance on democracy, see Allan C. Hutchinson, The Companies We Keep: Corporate Governance in a Democratic Society (Toronto: Irwin Law, 2005) at 59-83. 
It is against this backdrop that the present models of legal ethics and professional responsibility have developed. As part of a larger democratic compact, the existence of a large and powerful legal profession presents both a boost and a threat to the proper establishment and maintenance of democratic governance. On the one hand, a strong and forceful legal profession is a vital resource in holding governments to democratic account and guaranteeing that all citizens are empowered by vigorous representation in their dealings with governing bodies and other powerful elites. This task pushes towards a variety of rules and regulations which protect the legal profession's independence and entitle it to act as a bulwark between state oppression and citizens' freedom. On the other hand, in fulfilling that essential democratic task, there is a real danger that the legal profession will itself become an elite centre of power which will put its own interests ahead of those of its clients and that will fail to serve the broader public interest. This possibility suggests that a range of mechanisms will need to be put in place to ensure that the legal profession is held accountable to the public at large, and that its resources and prestige are not hijacked by any one segment of society. The challenge is to craft a set of regulatory, legal, and ethical arrangements that allow and require members of the profession to act in a way that satisfies the demands of democracy and the public interest by contributing to and facilitating the devolution and accountability of power. ${ }^{3}$

The underlying and animating model of the ethical lawyer is as a "special purpose friend" to his or her clients. ${ }^{4}$ As super-technocrats, lawyers are considered to possess a cultivated set of talents and techniques which they are supposed to deploy for the sole advantage of the people and private institutions who hire them. Positioned between the state and its citizenry, the legal profession is there to ensure that people are aware of their rights and are able to rely on them in dealing with the state or other private actors. As such, lawyers

3. I offer a very stylized and schematic account of the standard model of ethical lawyering. The fact that this model has severe limitations (e.g., insensitivity to the different needs of wealthier and poorer people) and is open to strong criticisms (e.g., differential access to legal services) is beyond the immediate scope of this paper. For a fuller discussion and a critical account, see Allan C. Hutchinson, Legal Ethics and Professional Responsibility, 2d ed. (Toronto: Irwin Law, 2006) at 19-59.

4. Charles Fried, "Lawyer as Friend: The Moral Foundations of the Lawyer-Client Relation" (1976) 85 Yale L.J. 1060. 
are to regard themselves as being neutral on the substance and form of the law as well as on their clients' agendas and interests. Not only is there no need for lawyers to act in solidarity with their clients' stance, but there are important political and moral reasons why lawyers should be consciously indifferent to their clients' causes and goals. This is because the relationship between lawyers and clients is built upon trust and respect: clients are to trust lawyers to act in the clients' best interests and, in return, lawyers will respect the clients' autonomy and interests. Within a largely adversarial system, lawyers' primary obligations are to their clients. While it is now excessive to suggest that they are "required to treat outsiders as if they were barbarians and enemies," lawyers are expected to be single-minded in their devotion to their clients' cause and to use whatever legitimate means are at their disposal to advance it.

The most obvious example of this uncompromising effort to act as a special friend in an adversarial setting is the traditionally conceived role and responsibilities of the criminal defence counsel. As accused individuals, citizens are pitted against the state, with all its resources and power, and are in urgent need of a friend who is always and unconditionally on their side. Charged with the task of raising a reasonable doubt, criminal lawyers are expected to commit themselves to doing all they can to ensure that their client is acquitted and that the state does not exercise its powers of punishment without respecting the rights of those it proceeds against, whether they are guilty or innocent. Of course, not all or even most lawyering is concerned with the criminal justice system. However, the criminal defence model holds great (and perhaps too much) theoretical sway in defining the basis and limits of lawyers' ethical role generally. The strict adversarial ethic has been largely transposed to the noncriminal law setting so that private lawyers are expected to adhere to a similar partisan role in representing their clients. Within such an account of lawyers in a democratic society, it will be apparent that lawyers are thought to advance the public interest by standing squarely in the citizens' corner and promoting or protecting their private interests against the government or against other citizens, in accordance with existing law and policy. As such, although this professional role is decidedly amoral, in that lawyers are not expected or required to take up their clients' interests and causes as their own or to defend them morally, it does have a strong moral and democratic underpinning.

5. Charles P. Curtis, "The Ethics of Advocacy" (1951) 4 Stan. L. Rev. 3 at 5. 
Under this traditional model of lawyering, the basic contours of the lawyerclient relationship take on a fairly obvious shape and substance. Apart from any general contractual obligations or tortious duties owed to the client, the lawyer is considered to be in a fiduciary relationship with the client. Consequently, lawyers are obligated to ensure that they act as zealous partisans on behalf of their clients, demonstrate undivided loyalty to and are entirely candid with their clients, avoid conflicts of interest, and give the highest confidentiality to their clients' communications. Moreover, it is generally accepted that one lawyer's client is considered to be the client of all the members in the retained lawyer's firm and, therefore, will be entitled to the same duties and obligations from all those lawyers as the circumstances allow: "it is the firm, not just the individual lawyer, that owes a fiduciary duty to its clients." Each of these obligations flows from the basic democratic account of professional roles and responsibilities. However, as part of the general compromise implicit in the democratic account, there are occasions on which lawyers must temper their zealous advocacy and loyalty in the public interest. Lawyers' adversarial zeal on behalf of clients is mitigated not only by competing duties to the courts (e.g., not to mislead) and the public (e.g., disclosure of future serious crimes), but also by the basic dury to one's self to be honest and honourable. Nevertheless, lawyers do owe special duties to their clients and are both entitled, and obliged, to give those interests priority in any clash with the interests of others. While those other interests might still count, they count for much less and, except in extraordinary circumstances, only when they are not in direct conflict with the interests of the lawyer's clients. ${ }^{7}$

\section{GOVERNMENT LAWYERS}

Of course, not all lawyers practice in the same circumstances. Indeed, it can be persuasively argued that it is no longer accurate or useful to talk about a

6. R. v. Neil, [2002] 3 S.C.R. 631 at para. 29. See also Allan C. Hutchinson, "Who are 'Clients'? (And Why it Matters)" (2005) 84 Can. Bar Rev. 411.

7. There is, of course, a less strict and softer interpretation of this traditional model which, although still retaining the primary duties of loyalty, zealous advocacy, and confidentiality, contends that unconditional loyalty to clients' interests will result in lawyers facilitating substantive social injustice. Instead, it places more emphasis on the broader secondary duties of the lawyer to the court and to third parties. See David Luban, Lawyers and Justice: An Ethical Study (Princeton: Princeton University Press, 1988). See also William H. Simon, The Practice of Justice: A Theory of Lawyers' Ethics (Cambridge: Harvard University Press, 1998). 
Canadian legal profession or a typical Canadian lawyer. ${ }^{8}$ Instead, there is now a multiplicity of roles and positions, ranging from the solo practice to the large corporate bureaucracy to the small partnership to government. The days of the fungible lawyer or legal practice are long gone. A diverse group of lawyers is engaged in a wide variety of practices. Who practises law (men and women, young and old, black and white, domestic and foreign, etc.), where they do it (e.g., office towers, shopping malls, clinics, home basements, government offices, mobile vans), how they do it (with entrepreneurial flair, part-time, on a shoestring, as big business, etc.), who they do it for (e.g., Aboriginal people, rich individuals, international conglomerates, homeless persons, small businesses), and what they do it for (e.g., subsistence income, personal satisfaction, enormous income, social prestige, political influence) have all gone through a transformation. It might be thought, therefore, that this changing landscape of professional practice would have significant implications for how the rules and models of ethical lawyering apply: different kinds of lawyers might be treated differently in terms of the ethical obligations placed upon them and the professional expectations demanded of them. Whether and how this will be done has not yet become clear.

Government lawyers-those who are employed by or sub-contracted to work for federal, provincial, or local governments, related agencies, and public bodies-are largely held to the same ethical standards and requirements as private lawyers. The almost complete silence of the various regulatory codes on the role and responsibilities of government lawyers can be reasonably assumed to recommend that there are no substantially different expectations of government lawyers. In a rare explicit acknowledgement of a possible distinction between the roles of private lawyers and government lawyers, the Code of Professional Conduct states that lawyers in public office must continue to maintain the same high standards expected of lawyers in private practice because their position "is in the public eye" and, therefore, "the legal profession can more readily be brought into disrepute" by misconduct. ${ }^{9}$ Although

8. Harry W. Arthurs, "Lawyering in Canada in the 21 st Century" (1996) 15 Windsor Y.B. Access Just. 202.

9. Canadian Bar Association, Code of Professional Conduct, c. 10, commentary, C. 1 [CBA, Code of Professional Conduct]. This more likely applies only to lawyers in elected office, but it can reasonably extend to government lawyers generally, even though it says and demands very little of them. 
American courts have occasionally placed a higher standard on government lawyers, Canadian courts have refused to hold government lawyers to a higher standard than lawyers in private practice. Indeed, one court has gone so far to say that "all lawyers ... are subject to the same single high standard of professional conduct" and that "it is not flattering to [other] lawyers ... to say that most of them are held to a lower standard of professional conduct than government lawyers." ${ }^{10}$ The most that seems to be conceded is that even though the general rules of professional conduct apply equally to government lawyers, there needs to be some adjustment and modest refinement in their application to those different situations which confront government lawyers.

Much of the day-to-day work done by government lawyers can be reasonably compared to that of private lawyers: they advise persons and institutions on existing laws and regulations, develop effective legal strategies, and then implement and vary those strategies as circumstances demand. However, this comparison only holds at a very superficial level. There is little similarity berween the work and situation of a solo practitioner or small partnership lawyer in a small town and that of a federal Department of Justice litigator. The overall context in which government lawyers operate is markedly different from that of private practice. Government lawyers are charged with the task of acting on behalf of government and placing the public interest ahead of the interests of any particular individual; there are many statutory, constitutional, and regulatory initiatives that impinge upon government lawyers. Private lawyers do not need to be directly, but only tangentially, concerned with the public interest (or, more accurately, attention to the clients' private needs is largely considered to be advancing the public interest). They also have a greater range of discretion in both whether they accept certain files or clients and under what circumstances they are prepared to withdraw from cases or discontinue their clients' representation. Because government lawyers

10. Everingham v. Ontario (1992), 8 O.R. (3d) 121 at para. 18 (Div. Ct.). The CBA also states that "the lawyer who holds public office should, in the discharge of official duties, adhere to standards as high as those that these rules require of a lawyer in the practice of law." See CBA, Code of Professional Conduct, ibid., r. 10. See also Law Society of Upper Canada, Rules of Professional Conduct, r. 6. However, I will not deal with the particular responsibilities and duties of elected officials, like the Attorney General or Minister of Justice. See Kent Roach, "Not Just the Government's Lawyer: The Attorney General as Defender of the Rule of Law" (2006) 31 Queen's L.J. 598. 
are both legal practitioners and employees, they are more restricted in their options. However, in this one regard at least, government lawyers are in not so different a position from junior associates in large metropolitan law firms: they have little choice about who they represent, what files they take, and how they manage those files. Both the large firm lawyer and the government lawyer must follow instructions in all ethical and professional matters unless they are prepared to take an employment-threatening stance."

The significant difference between private lawyers and government lawyers is that the latter have a much greater obligation to consider the public interest in their decisions and dealings with others than the former. This is parricularly so in the case of the criminal prosecutor. Because prosecutors fulfill a "public function," it must be carried out "fairly and dispassionately."12 Consequently, the duty of prosecutors is not to seek convictions, but to adopt an almost quasijudicial obligation which excludes any notion of winning or losing. The prosecutor's duty "is not to seek a conviction," but to present all "credible" and "relevant" evidence to the court so "that justice may be done through a fair trial. ${ }^{13}$ As such, prosecutors operate in a dual capacity: as a partisan advocate (i.e., they must seek convictions for the guilty) and as a court administrator (i.e., guard against the wrongful convictions of the innocent). These different roles and responsibilities were made clear by Justice Rand in Boucher.

It cannot be over-emphasized that the purpose of a criminal prosecution is not to obtain a conviction; it is to lay before a jury what the Crown considers to be credible evidence relevant to what is alleged to be a crime. Counsel have a duty to see that all available legal proof of the facts is presented: it should be done firmly and pressed to its legitimate strength, but it must also be done fairly. The role of prosecutor ... is a matter of public duty [and] there can be none charged with greater personal responsibility. It is to be efficiently performed with an ingrained sense of the dignity, the seriousness and the justness of judicial proceedings. ${ }^{14}$

It might also be contended that in the same way that criminal lawyers can be considered to be in a different position from private lawyers, government lawyers might also be viewed generally as operating in a significantly different

11. I will pursue this important point in Part $\mathrm{V}$, below.

12. CBA, Code of Professional Conduct, supra note 9, c. 9, commentary, s. 9.

13. Ibid.

14. R. v. Boucher, [1955] S.C.R. 16 at para. 26 [Boucher]. See also R. v. Trochym, [2007] 1 S.C.R. 239. 
context than their prosecutorial colleagues. Yet this contention seems less convincing - the differences between criminal lawyers and private lawyers are much more significant than those between government lawyers generally and prosecution lawyers specifically: prosecution lawyers are a species of government lawyers, not an entirely different genus. While they do not fulfill exactly the same roles or assume exactly the same obligations, government lawyers and prosecution lawyers both share a common duty to advance the public interest as a direct and explicit undertaking. Indeed, it can be argued that all government lawyers, including prosecution lawyers, are government bureaucrats first and lawyers only second. Each of them is involved in the important task of formulating and implementing government policy within a specified and sophisticated structure of constitutional, legislative, administrative, and judicial requirements. This difference in roles and responsibilities can be analogized to the division between the laws and regulations which govern the operation and orientation of private and public bodies generally. The development of constitutional and administrative law has been marked by the approved imperative to hold public actors to different standards of conduct and accountability than their private counterparts. ${ }^{15}$ Informed by a distinctly democratic sensibility and commitment to the public interest, courts have required public bodies to look to a broader set of interests than their own parochial and partisan concerns in determining the most appropriate and reasonable course of action to be followed. In short, like the bodies that they serve and represent, government lawyers are different in that they are expected to have a more expansive and more public appreciation of their roles and responsibilities than their private counterparts.

\section{IN THE PUBLIC INTEREST}

It can be insisted, therefore, without too much serious resistance, that government lawyers are differently situated than private lawyers in that their work takes place more directly in the immediate field of the public interest. However, because there are so many competing notions of what comprises the public interest and how it should apply in particular situations, it is a notoriously

15. See e.g. Peter W. Hogg, Constitutional Law of Canada, 5th ed. (Scarborough: Thomson Canada, 2006). See also David Phillip Jones \& Anne S. de Villars, Principles of

Administrative Law, 4th ed. (Scarborough: Thomson Canada, 2004). 
difficult and contested task to designate what ends are in the public interest and what means-which must also be consistent with the public interest-are best pursued to realize those ends. There is no certainty as to what those values are and even less on what they demand in particular situations: democracy is premised on the belief that such determinations are inherently political and are best made by the people themselves. However, in seeking to fix and frame the ethical obligations and professional responsibilities of government lawyers, there is no compelling need to enter into that sprawling debate in any definitive or exhaustive way. The more modest and pertinent question concerns the role and responsibilities that government lawyers do and should have in explicating or contributing to the government's duty to act in the public interest. Fortunately, reference back to a democratic appreciation of the public interest can point to possible answers to that central quandary.

In any populous and contemporary society, there will have to be certain trade-offs in how the government works and how power is allocated and exercised. Democracy is no exception. While it will be important to maximize the circumstances and settings in which popular participation occurs, there will be limits on how this can be done. Problems of scale and efficacy suggest that compromises will need to be made. For instance, it must be determined how many people will be involved in the general governance and decision-making process of society, for how long they will be involved, and by what method they will be selected and/or removed. However, in settling on the kind and manner of such compromises, it will be important to make such trade-offs within a democratic account of governance and not with a democratic account of governance. This means that while it will be necessary to confer public power on some persons over others at times, the role of those people presently out of power will not be exhausted by occasional electoral involvement; democracy is a mode of government by the people as well as for them. Even citizens who are not involved in government and public-interest decision making have a responsibility to keep a watchful eye on those in power and to hold them accountable. As such, both those in power and those out of power have mutually-reinforcing duties and obligations to advance and maintain the democratic project. Accordingly, a democratic approach to the problems of the allocation and exercise of power will likely work along two axes: participation and accountability. 
The participatory imperative is intended to maximize the opportunities not only for popular involvement in decision making and policy implementation, but also for ultimate responsibility for those tasks. Democracy is not intended to be a supplement to or cover for rule by an expert elite. While elected officials would do well to seek the advice of experts, it is entirely their choice as to whether they follow that advice. Of course, because these political delegates are given such extensive power and responsibility, an accountability check becomes essential; democracy must guard against the power-hogging tendencies of elected officials as much as any other group. This gives rise to the accountability imperative: elected officials must be answerable to the other citizen $\dot{s}$ who they represent and on whose behalf they act. Along with the usual electoral processes and more discipline-oriented measures, it will be important to ensure that the practice of democratic governance is as open and transparent as possible. Without the necessary information about what government decisions are made and how they are made, the citizenry will be unable to exercise its own democratic responsibilities and rights in overseeing public officials and in deciding whether to re-elect them. Consequently, the role of public officials involves a democratic quid pro quo. While those in power by virtue of the extant democratic processes might obtain certain temporary privileges and priorities, they can also expect to be placed under much greater scrutiny and appraisal than other persons in exercising that power. Quite simply, the accrual of public power carries with it the moral and institutional obligation to exercise it in the public interest and to be seen to do so. By relying on both participation and accountability, the necessary trade-offs in establishing genuine democratic governance in large societies can be made within rather than with democracy.

This democratic understanding of the allocation and exercise of public power recommends some particular responses to the challenge of determining the role and responsibilities of government lawyers. As regards zealous advocacy and confidentiality, such a democratic sensibility seems to pull in two different ethical directions: it favours close adherence to the traditional model of private lawyering in some instances and deviations from it in others. For instance, as regards zealous advocacy, it seems to suggest that insofar as government lawyers are expected or directed to act in the public interest, they will take their lead from their political superiors and defer to such officials on what the public interest demands in deciding on policy and implementing it. However, as regards confidentiality, although they will not be permitted to act wantonly or 
capriciously, they will be under a less onerous obligation to keep work-related communications and information confidential. Indeed, when assessed from the public interest, government lawyers might well have a professional duty in some circumstances to disclose publicly certain communications and information. Government lawyers will determine their moral compass by the requirements of maintaining a loyal and keen friendship not with their political superiors or government as such, but with the public interest more generally. Public officials are entitled to loyalty from government lawyers not directly, but by virtue of their roles as the democratic guardians of the public interest. Both of these positions on zealous advocacy and confidentiality need further elaboration and justification.

\section{ZEALOUS ADVOCACY}

At the heart of private lawyers' duty of loyalty to their clients is the obligation to act as their zealous advocate. This demands a single-minded focus on clients' interests. As Lord Brougham declaimed in defending the English queen against treason charges, the lawyer's duty is "to save that client by all means and expedients, and at all hazards and costs to other persons, and ... in performing this duty he must not regard the alarm, the torments, the destruction which he may bring upon others." 16 Although that degree of passionate commitment might not be required today, it is only in exceptional and relatively extreme circumstances that lawyers are expected to curb their unconditional enthusiasm for their clients' interests in the name of the public interest. Moreover, even if this standard were to be applied to government lawyers, it would demand certain concessions. Lord Brougham's exhortation that lawyers must be prepared to separate "the duties of a patriot from those of an advocate, and cast[] them, if need be, to the wind" and to "go on reckless of the consequences, though it should be his unhappy fate to involve his country in confusion"17 hardly fits easily with the role of the modern government lawyer. Presumably in acting in the public interest, government lawyers are to advocate on behalf of the government, not against it, and will be sensitive to the country's fate.

Whether by design or default, government lawyers will have an important role to play in thinking through and answering contentious and crucial matters

16. J. Nightingale, ed., Trial of Queen Caroline, vol. 2 (London: J. Robins \& Co., 1821) at 8.

17. Ibid. 
about what ends and means are in the public interest. It is difficult to take seriously any suggestion that government lawyers should have no legitimate or effective role at all in such policy formation and implementation. Government lawyers can and should make a valuable contribution in shaping discussion about what represents the public interest in any particular instance. However, the crucial issue is who gets to determine what is in the public interest when governments lawyers disagree or, more pertinently, when government lawyers and their political and/or elected superiors disagree. It is difficult to make a strong claim that government lawyers should have the final and determinative call on what is in the public interest under a strictly democratic model of good governance and ethical lawyering. It would be undemocratic and perhaps even anti-democratic for government lawyers to be authorized by the legal profession as a matter of ethical discretion or professional responsibility to put their own views on the public interest ahead of the views of public officials. As an elite group of expert professionals, lawyers have no better and perhaps worse claims to determine what is in the public interest than elected officials, or even citizens generally. As John Hart Ely might have said, "we may grant until we're blue in the face that [elected officials] aren't wholly democratic, but that isn't going to make [lawyers] more democratic than [elected officials]." ${ }^{\text {18 }}$ As such, a commitment to democracy strongly recommends that aside from proposed courses of criminal or illegal conduct, government lawyers should not have any kind of veto over such determinations of the public interest by elected officials or political superiors. Indeed, after exhausting all opportunities for persuasion and discussion, government lawyers must advance the determined goals or strategies with customary enthusiasm or give up their position. Under any account of legal ethics or public interest, there is simply no role for half-hearted professional advocacy.

In developing and defending this general stance, there are two related aspects of the current understanding about lawyers' professional responsibilities

18. Although this is a bastardized version of Ely's original quote that "we may grant until we're blue in the face that legislatures aren't wholly democratic, but that isn't going to make courts more democratic than legislatures," it is intended to be in the spirit of Ely's original quote. See John Hart Ely, Democracy and Distrust: A Theory of Judicial Review (Cambridge: Harvard University Press, 1980) at 67. For views along a similar line, see Geoffrey Miller, "Government Lawyers' Ethics in a Sysrem of Checks and Balances" (1987) 54 U. Chi. L. Rev. 1293 at 1294. See also Pèter L. Strauss, “The Internal Relations of Government: Cautionary Tales From Inside the Black Box" (1998) 61 Law \& Contemp. Probs. 155 at 156-57. 
that can be profitably examined: client identity generally and corporate representation specifically. First, it might be useful to come at this problem as if government lawyers are part of a traditional lawyer-client relationship. This would initially demand some appreciation of the identiry of the client that they are intended to serve. This is by no means obvious. There are a number of candidates: the government as a whole; the branch of government in which the lawyer is employed (i.e., executive, legislative, or judicial); the particular agency or department in which the lawyer works; the responsible officers who make decisions for the agency; and the public interest itself. ${ }^{19}$ Because the professional codes seem to assume that government lawyers will be bound by similar ethical duties as their private counterparts, they have little if anything to say on this important choice between the likely alternatives. However, the Alberta Code does state that "the client of a lawyer employed by the government is the government itself and not a board, agency, minister or Crown corporation." ${ }^{20}$ Accordingly, even if the government, broadly understood, is the client or even if it is something as abstract as the public interest itself, the more pertinent question is not "who is the client?" but "who gets to speak on the client's behalf?" In either case, it seems unlikely thar government lawyers have any prior or privileged claim to make that call on behalf of the citizenry at large as compared to other government officials. After all, that would in effect make government lawyers their own clients and they would have no greater responsibility than to take bona fide instructions from themselves.

Accordingly, from a democratic perspective, it can be argued that whether it is the government generally or the public interest at large that is to be served by government lawyers, there is no compelling reason why the government lawyer's view as to what to do should take precedence over the view of elected officials and/or political superiors. ${ }^{21 .}$ Of course, government lawyers have a significant contribution to make in debates within government about how to

19. Roger C. Cramton, "The Lawyer as Whistleblower: Confidentiality and the Government" Lawyer" (1991) 5 Geo. J. Legal Ethics 291 at 296.

20. The Law Society of Alberta, Code of Professional Conduct, c. 12, r.1, commentary, C.1.

21. For a defence of the position that a lower standard of loyalty is owed by government lawyers as a result of the public interest or the common good, see Steven K. Berenson, "Public Lawyers, Private Values: Can, Should, and Will Government Lawyers Serve the Public Interest?" (2000) 41 B.C.L. Rev. 789 and "Rethinking the Professional Responsibilities of Federal Agency Lawyers," Note, (2002) 115 Harv. L. Rev. 1170. 
determine what the public interest demands; they often have the training, experience, and knowledge to help develop a nuanced and sophisticated approach to identifying the public interest and crafting a range of practical strategies for its realization in difficult circumstances. Indeed, being relatively independent of political pressures and partisan agendas, government lawyers are well placed to act as trusted advisors to their political superiors. They can adopt a broader and deeper perspective on how the public interest can be advanced, anticipate the response of courts to particular arguments and directives, and caution their political superiors on legal and policy tactics that might backfire. Nevertheless, it is incumbent on government lawyers to leave the final decision on what government policy and legal strategy should be adopted and implemented to elected officials. As such, I can do no better than echo approvingly the wise words of Henry Hart and Albert Sacks:

Government lawyers, of course, have a wide variety of responsibilities as advisers to other officials. ... These responsibilities are akin to those of a private lawyer when he [or she] advises a private client, and they include the same inescapable residuum of personal responsibility which is inherent in the exercise of any profession. Indeed, in the case of a government lawyer this personal responsibility not merely to give accurate advice but to try to guide decision so as to keep it within proper bounds has a special urgency, for a lawyer's client is not merely the official whose action is immediately in question but the government of which the official is a part and in some sense the whole society for which the government speaks. Nevertheless, the power and the ultimate responsibility of decision in these situations belong to the official whom the lawyer advises. The lawyer acts essentially in a staff capacity, and has always to remember this. ${ }^{22}$

Although government lawyers are in a different position than private lawyers, a useful analogy can be drawn to the context and challenges faced by those lawyers who represent corporations or other similar organizations. While it is clear and undisputed that the corporation itself is the client for the purposes of the lawyer's ethical obligations, it remains less settled as to how this relationship is to be operationalized in light of the fact that a corporation only exists as an abstract entity. As a general matter, it can be stated that the lawyer's ultimate obligation of allegiance is to the corporation itself and not to any of its officers, shareholders, employees, or other persons who might control the

22. Henry M. Hart, Jr. \& Albert M. Sacks, The Legal Process: Basic Prablems in the Making and Application of Law, ed. by William N. Eskridge, Jr. \& Philip P. Frickey (Cambridge: Cambridge University Press, 1994) at 1047. 
corporation. ${ }^{23}$ However, it is plain that corporate lawyers are not entitled to determine for themselves what is in the best interests of the corporation and how best to protect or promote those interests. In any dispute or disagreement about how the corporation should be represented, the individual person designated to speak on behalf of the corporation by its board of directors has the first and last call. Corporate lawyers can and should contribute to that debate, but they are not at liberty simply to prefer their own sense of what is in the corporation's best interests. ${ }^{24}$ Consequently, like corporate lawyers, government lawyers would be well advised, on assuming their position as a government lawyer or accepting any file, to obtain express clarification as to which individuals have authority to instruct them on behalf of the government or public interest.

If there are good democratic reasons why private lawyers should be required to defer to their clients' own assessments of their best interests, there are even stronger reasons why government lawyers should defer to the assessments of democratically elected and popularly accountable officials as to what constitutes the public interest. It seems almost axiomatic that if the public is in the best position to assess the public interest, then its representatives are in a better position than lawyers to do so. There is a temptation to suggest that citizens do not always know what is best for them, but this is exactly the kind of elitist thinking that democracy rejects and seeks to overcome. Like judges, lawyers can claim no special insight or privilege in evaluating what is in the public interest. Indeed, also like judges, they might confuse established or special interests with what is in the public interest, more generally construed. The legal profession as a whole can hardly be portrayed as a bastion of popular or progressive thinking or as unerring calculators of the public good. Historically, they have a mixed record in their efforts to give substance to the public interest over the years and in particular instances. ${ }^{25}$ Moreover, apart from

23. CBA, Code of Professional Conduct, supra note 9, c. 5, commentary, C.16.

24. Nevertheless, as I discuss below, there might well be some extreme circúmstances in which corporate lawyers could be required to question and occasionally ignore the instructions of the person who has been designated to speak on behalf of the corporation.

25. This is not the place to offer chapter-and-verse support for such a relatively moderate assessment. Suffice it to say that there are as many specific instances of lawyers and judges getting it wrong as opposed to right in advancing the public interest. See e.g. J.A.G. Griffith, The Politics of the Judiciary, Sth ed. (London: Fontana Press, 1997) and Allan C. Hutchinson, Evolution and the Common Law (Cambridge: Cambridge University Press, 2005). 
their dubious judgment on such matters, any plea by or on behalf of government lawyers to be allowed to pursue their own rendition of the public interest over that of their political superiors will also have the effect of holding the public interest hostage to one more elite group. No matter how well intentioned that group of government lawyers might be, such a state of affairs will be almost anathema to the committed democrat.

This stance may well mean that government lawyers will be asked to take positions or pursue tactics with which they strongly disagree or which they might think to be against the public interest. This is an institutional price that will have to be paid, because democracy is not so much about getting the right answers, insofar as they can ever be said to exist, but about who gets to make difficult decisions. However, in being required to accede to the lawful instructions of their political superiors, government lawyers are in no worse position than private lawyers. Government lawyers' deference regarding the determination of the public interest to officials with a better democratic mandate than their own is not as significant a problem as some protest, as there are often lawyers on the other side or judges who are able to declare such views of the public interest to be wrong-headed or even illegitimate. Moreover, if government lawyers find themselves in situations in which they no longer feel able to represent a certain objectionable position, make a certain objectionable argument, or pursue a particular legal strategy, they will have to consider whether they can or should remain in their present employment. Further, there is no expectation that they breach legal rules or statutory regulations as a matter of professional responsibility; no professional code allows lawyers to act illegally under the supposed ethical cover of zealous advocacy.

As with private lawyers, there are no easy answers or solutions to ethical dilemmas involving government lawyers. It is simply naive or self-deluding to pretend that legal professionals, be they private lawyers or government lawyers, can expect to arrange their lives so that they not only always get to do what they want, but also have such a course of action approved as being ethically virtuous or even merely acceptable. Being ethical and being a lawyer can be exacting, inconvenient, and even harmful to the lawyer's own interests. This ought to come as no surprise because it is what makes law a profession as much as a business and emphasizes the onerous side of the power-responsibility equation. While government lawyers may occasionally have to forego their employment (or at least threaten such a move), they should expect no special 
dispensation in fulfilling the ethical duties and professional responsibilities of their chosen profession.

\section{CONFIDENTIALITY}

Up to now, it might be reasonably thought that, although I have argued that government lawyers are in a different position than private lawyers and that their ethical obligations may be correspondingly different, the role and expectations of government lawyers is no different than those of their private counterparts-while acting in the public interest, they must ultimately defer to the views of their superiors as to what ends and means are in the public interest. However, though government lawyers must act as zealous advocates of the government's view of the public interest, this does not mean that their other ethical duties and professional responsibilities will fall entirely into line with those of private lawyers. If government lawyers are to advance the public interest (as determined by their political superiors), this will pull in different directions in crafting the precise impact upon their professional responsibilities when measured against the private benchmark. In particular, government lawyers are in a different position when it comes to the demands of confidentiality. In short, the same democratic-based arguments that recommend that government lawyers should be the government's zealous advocates also support the proposal that they should not be under the same regime of ethical expectations in regard to maintaining confidentiality.

The traditional model of ethical lawyering places a strict duty on private lawyers to keep their clients' communications on legal matters entirely to themselves. It inures to the benefit of clients, not lawyers, and can only be waived with the client's clear approval. Although confidentiality cannot be used as a cover for criminal communications, the duty prevents lawyers from utilizing or publicizing information received for their own or anyone else's benefit. The demands of this duty are relarively uncompromising and can only be breached by lawyers in exceptional circumstances - to defend themselves against allegations of criminal conduct, civil liability, or professional misconduct; to establish or collect their fees; and to avert an imminent risk to an identifiable person or group of death or serious bodily harm. ${ }^{26}$ Even when

26. Smith v. Jones, [1999] 1 S.C.R. 455 at para. 77. 
they are permitted to reveal privileged communications, they may only do so in the most restricted way that least adversely affects their clients' interests. Moreover, the duty of confidentiality does not expire when the lawyer no longer represents the client. However, when the rationales offered for enforcing such a strict duty among private lawyers are examined in the setting of government lawyers, their application in terms of their force and reach is by no means readily apparent. Indeed, the reasons for insisting upon such a duty of confidentiality have far less cogency in regard to government lawyers.

The established basis for the duty is that clients must be able to confer with their lawyers so as to ascertain and protect their legal rights. In order to obtain full and frank legal advice, it is considered appropriate that clients should have no fear that those communications will become public and possibly be used against them. It is considered that the public interest is best served by placing such communications outside public scrutiny, even if that might seriously impair the search for truth: the sanctity of certain relationships (e.g., the lawyer-client relationship) is deemed to have sufficient social significance to outweigh the priority given to the ascertainment of truth in the legal process. In the leading contemporary Canadian case, the Supreme Court offered a convenient summary of the lawyer-client privilege:

Solicitor-client privilege describes the privilege that exists between a client and his or her lawyer. This privilege is fundamental to the justice system in Canada. The law is a complex web of interests, relationships and rules. The integrity of the administration of justice depends upon the unique role of the solicitor who provides legal advice to clients within this complex system. At the heart of this privilege lies the concept that people must be able to speak candidly with their lawyers and so enable their interests to be fully represented. ${ }^{27}$

Although this privilege has considerable, if not irresistible, appeal in the context of private individuals and their lawyers, especially in the criminal law context, it loses much of its credibility and gravitas when transferred to the situation of government lawyers. Insofar as the rule of confidentiality is meant to protect the relatively powerless citizen against the state by ensuring effective legal representation through open communication, it does not seem either necessary

27. Pritchard v. Ontario (Human Rights Commission), [2004] 1 S.C.R. 809 at para. 17 [Pritchard]. The classic statement of this justification is offered by Lord Brougham in Greenough v. Gaskell (1833), 39 E.R. 618 at 620-21. 
or useful when the government is the putative client being protected. ${ }^{28}$ While government business is important, it has no need of such privileges and protections. The dignity and vulnerability of individuals is not at stake in the same way. Indeed, the basic democratic commitment to openness and transparency as a vital prerequisite for accountability suggests that there is very little role for confidentiality in the affairs of government: confidentiality and open government do not sit at all well together.

In Pritchard, a disgruntled complainant sought production of an opinion from the Ontario Human Rights Commission's in-house lawyer. The Court held that solicitor-client privilege applies "with equal force in the context of advice given to an administrative board by in-house counsel as it does to advice given in the realm of private law." ${ }^{29}$ The Court refused to make any distinction at all between the role of government lawyers and private lawyers. This is surely a short-sighted decision. Government lawyers clearly have an obligation to pursue the public interest, not simply the private interests of their government client. Although the precise scope of that obligation might well be contentious, its existence and good sense is surely not. On its facts, it is difficult to appreciate why the Commission should be able to hide behind lawyer-client privilege as a way of frustrating the complainant's efforts to learn why her complaint was rejected. The opinion pertained to a public body's fulfillment of its explicit public interest mandate; there was no pending litigation where the recognition might be more compelling. As such, the Court's failure in Pritchard to recognize any distinction between privare lawyers and government lawyers is regrettable and flies in the face of basic democratic and institutional realities.

After all, the absolute duty of confidentiality is already under steady criticism in the corporate context, where the broad interpretation of privileged communications has begun to persuade some commentators and regulators that it might be desirable to place certain limitations and restrictions on the duty. ${ }^{30}$ The need to facilitate the flow of information between the corporate

28. See Lory A. Barsdate, "Attorney-Client Privilege for the Government Entity" (1988) 97 Yale L.J. 1725 and James E. Moliterno, "The Federal Government Lawyer's Duty to Breach Confidentiality" (2005) 14 Temp. Pol. \& Civ. Rts. L. Rev. 633.

29. Pritchard, supra note 27 at para. 21.

30. See William H. Simon, The Practice of Justice: $A$ Theory of Lawyers' Ethics (Cambridge: Harvard University Press, 1998) at 55 and Daniel R. Fischel, "Lawyers and Confidentiality" (1998), 65 U. Chi. L. Rev. 1. 
organization, its employees, and its lawyers seems much less compelling than in the case of the isolated citizen who must deal with the state and its government departments. Out of concern that the duty is being utilized too easily to hide corporate mischief and even criminality from appropriate public scrutiny, there are efforts to restore a greater sense of balance between the need for confidentiality and the need for publicity so that greater weight is given to the public interest in determining appropriate occasions of required disclosure or perhaps noisy withdrawal. ${ }^{31}$ Consequently, the reasons for maintaining strict confidentiality in such circumstances are less persuasive.

Similarly, even if there is to be a general duty on government lawyers to keep confidential communications between themselves and their political superiors and colleagues, it should be severely curtailed. If there are strong arguments against protecting the internal workings of corporations from public scrutiny, there are fewer reasons to do so in the case of governments. In a recent case, the Ontario Court of Appeal held that, based on broad Charter ${ }^{32}$ considerations, government can be obliged to disclose information which falls within the traditional lawyer-client privilege if there is a strong public interest in so doing; this was notwithstanding exemprions in pertinent access to information legislation. ${ }^{33}$ While this decision speaks to the circumstances in which the government "client" is obliged to reveal what is otherwise privileged information (as opposed to the government lawyer), it points in the right democratic direction. As such, it is preferable to the dubious thrust of the Pritchard decision.

While it would be inappropriate to move to a situation in which government lawyers have no responsibility at all to preserve some degree of confidentiality in their professional activities, the public interest rationale supports the conclusion that any such duty should certainly cease to apply where the lawyer is no longer in the employment of the government and, more

31. See e.g. "After Sarbanes-Oxley: A Panel Discussion on Law and Legal Ethics in the Era of Corporate Scandal" (2003) 17 Geo. J. Legal Ethics 67. For a general defence of the rationale for easing the confidentiality burden on government lawyers, see Christine Harrington, "Reevaluating the Duty of Confidentiality," Note, (2003) 47 N.Y. L. Sch. L. Rev. 423 and Daniel R. Fischel, "Lawyers and Confidentiality" (1998) 65 U. Chi. L. Rev. 1.

32. Canadian Charter of Rights and Freedoms, Part I of the Constitution Act, 1982, being Schedule B to the Canada Act 1982 (U.K.), 1982, c. 11, s. 7 [Charter].

33. Criminal Lawyers Association. v. Ontario (Ministry of Public Safety and Security) (2007), 86 O.R. (3d) 259 (C.A.). 
contentiously, even when still in government employ. Moreover, it would be advisable if former or present government lawyers did not breach confidences unless they had made a good faith decision that the public disclosure of such communications was strongly in the public interest. Although this would put lawyers in the position of determining the public interest (which I frowned upon and resisted in the context of zealous advocacy), it would only occur where lawyers were so concerned about public officials' mistaken or perverse reliance on the public interest that they were prepared to run the risk of relinquishing their positions as government lawyers. This is a heavy burden and might convince some that government lawyers should benefit from a lower threshold at which they would become empowered to blow the whistle on government misfeasance in regard to the public interest. Nevertheless, the major thrust of a democratic approach to the duty of confidentiality is that it is at best a rebuttable presumption. ${ }^{34}$ Government lawyers might well better serve the public interest by breaking confidentiality than preserving it.

Another beneficial consequence of a looser obligation on government lawyers to keep confidences is its effect on the relationship between government lawyers and their political superiors. While government lawyers must be subservient to elected leaders and political officials in regards to what counts as the public interest in determining policy ends and legal means, those officials might begin to feel a little more pressure to ensure that they are acting in good faith in settling upon the demands of the public interest. Mindful that the bounds and demands of confidentiality were looser and that government lawyers might at some point in the furure reveal their superiors' inappropriate motives, those superiors might be inhibited from using the public interest as a cover for crass or improper purposes. Elected officials would still have at their disposal the necessary statutory protection of state secrets to ensure that information held by government lawyers or communications with them that legitimately jeopardized national security would remain out of the public domain. However, outside of this special kind of information and communication, it is entirely in accord with democracy and more attuned to

34. For a defence of the position that government lawyers are duty-bound to keep in strict confidence all communications and information, see Catherine J. Lanctot, "The Duty of Zealous Advocacy and the Ethics of the Federal Government Lawyer: The Three Hardest Questions" (1991) 64 S. Cal. L. Rev. 951 at 1012-13. 
the public interest to cultivate a government culture in which openness and transparency, not secrecy and obfuscation, are the order of the day. In this way, government lawyers will help citizens to better fulfill their continuing democratic responsibility to monitor and oversee the operation of government.

\section{CONCLUSION}

If this brief democratic inquiry into the theoretical role and responsibilities of government lawyers suggests anything, it is that the role and responsibilities of private lawyers are in need of more serious evaluation and revision. The democratic arguments as to why lawyers should act as the zealous and loyal advocates of private interests are not easy to reconcile with the public interest dimensions of democratic governance. Although it is undoubtedly in the public interest that people be free to promote and protect their own private interests, there is no reason why the vast resources and talents of the legal profession should be so unconditionally organized and deployed in line with those private interests. Insofar as there is a mandate for the traditional model of special friends at all, it would seem that it must be more evenly balanced and calibrated in favour of a more ample understanding of the public interest. Because the exclusive advancement of private interests will not always inure to the benefit of the larger society (except perhaps in the austere imagination of the unreconstructed free-market theorist), it behooves a democratic society to realign its stance on legal ethics so that it better incorporates a more public vision of lawyers' professional role and responsibilities. However, there is no reason to throw good money after bad by making the ethical obligations of government lawyers hostage to the traditional model of professional duty, or even to utilize that model as the only baseline against which to determine and measure the different role and responsibilities of government lawyers. As their importance to policy making and policy implementation becomes more apparent, government lawyers should have their professional responsibilities and ethical expectations regulated and disciplined with the special circumstances and conditions of their professional lives clearly in mind. 
